\title{
Family and Upbringing Background of Students with Bullying Behavior in Islamic Private Schools, Pattani Province, Southern Thailand
}

\author{
Kasetchai Laeheem ${ }^{1}$ \\ ${ }^{1}$ Faculty of Liberal Arts, Prince of Songkla University, Hatyai, Thailand \\ Correspondence: Kasetchai Laeheem, Faculty of Liberal Arts, Prince of Songkla University, Hatyai, Songkhla \\ 90110, Thailand. E-mail: Lkasetchai@yahoo.com
}

Received: February 11, 2013 Accepted: March 21, 2013 Online Published: June 1, 2013

doi:10.5539/ass.v9n7p162 URL: http://dx.doi.org/10.5539/ass.v9n7p162

\begin{abstract}
The purpose of this research is to investigate family and upbringing background of students with bullying behavior in Islamic private schools in Pattani Province, Southern Thailand. The data for this qualitative study were collected through in-depth interviews with 15 teachers and school personnel, 15 bullying students, 15 bullied students, and 15 parents and guardians. Content analysis was performed with the data using logics, concepts, theories, research reports along with the context, and grounded theory method.

The results of the study revealed that family and upbringing background had effects on students' behavior. Upbringing characterized children's behavior, especially children who were faced with domestic violence such as parents' quarrels, and children being severely punished, etc. that might result in children absorption and imitation of such violence. The results of this study are beneficial directly to personnel and organizations related to children in policy making and measure taking in order to provide help and improve the problem of bullying so as to make students behave appropriately, and to prevent students from behaving more violently.
\end{abstract}

Keywords: family and upbringing background, students, bullying behavior, Islamic private schools

\section{Introduction}

Bullying among students is considered a problem usually happens in schools and it is a problem that all parties concerned know very well, whether it is between students themselves or parents and guardians, teachers, and educational personnel. The problem is worrisome and it affects students who are involved whether they are the bullies or being bullied. Students who are bullied are usually injured, suffered, do not like going to school and bullying becomes bad memory that remains in their memory until they are grown up. For the bullies who bully others repeatedly, bullying becomes a habit that can make them become vulgar, aggressive, savage, delinquent adults, and may ultimately become criminals (Farrington, 1993).

Bullying is behavior of roguish children beginning from unfairly controlling others physically, mentally, emotionally, and feeling-wise. Such behavior intentionally hurts others physically and psychologically so that they are frightened, suffered, and injured. This type of behavior is usually performed by a group with more members, and who are physically bigger and stronger. These bullying children force, and emotionally and psychologically hurt children who are weaker or have impaired body parts or physically disabled, and the incident usually happens to the same persons continually and consistently (Marano, 1995; Coloroso, 2003). Such behavior is performed using strength and bad temper to threaten others intentionally, and the action is unwanted and pungent to the other party (Baron, 1996; Astor, Meyer, Benbenishty, Marachi, \& Rosemond, 2005). It is an action that invades others' right by threatening, forcing, demanding, or acting violently (Chanhom, 1998). Even though bullying behavior in schools nowadays are prevalent, and affects students to a great extent, society usually overlooks bullying and takes it as normal behavior, over-teasing, or innocent behavior among children, and therefore does not pay attention to solving the problem as seriously as it should (Tapanya, 2006).

From reviewing related literature, especially theories and research, it was found that there are many causes of bullying but the main causes are family and upbringing background. Children from families where parents divorce or separate may feel lonely. Parental divorce and separation directly affect children's emotion. Children from families with moody parents who show bad temper, anger, and aggressiveness, and scold their children 
strongly may also make their children become the same as they are, and all of these can affect children's behavior (Arayawinyu, 1999). Students who live in the environment with domestic violence have more risk to express violence or injure others (Pepler \& Sedighdeilami, 1998; Rossman, Hughes, \& Rosenburg, 2000). Parents that show their aggressiveness, trespass, and conflicts may result in children imitating all these behaviors and express them through threatening and injuring others (Bandura, 1975; Jeffe, Wolfe, \& Wilson, 1990). Students who have experience seeing their parents physically injure each other are very likely to bully others (National Research Council, 1993; Dauvergne \& Johnson, 2001). Moreover, children who live in a situation where their parents have conflicts, quarrels, and physically injure each other tend to imitate their parents' behavior. As a result, they become bullies and they bully others when they have social interactions with other people (Edleson, 1999; Herrera \& McCloskey, 2001).

From above, it can be seen that bullying behavior among students is still an unsolved problem that requires attention from related individuals and organizations. The problem needs to be solved, especially in schools in the southern part of the country where the unrest situation exists. Thus, studies by many academics found that 20.7 percent of Thai Muslim youths in the three southern border provinces had bullying behavior, and 22.3 percent had aggressive behavior (Laeheem \& Baka, 2011). They also found that most youths or 31.7 percent participated in the unrest situation because they wanted money, followed by 22.2 percent who did not know what they were involved in; 21.9 percent were swindles; 13.9 percent were drug addicts; and 10.3 received wrong religious teaching, respectively (Laeheem \& Baka, 2010). In the unrest situation in the southern part of Thailand, more than 90 percent of the insurgents were found to be Muslim youths aged 18-35 years (The Southern Border Provinces Police Operations Center, 2006). In Pattani Province, 23.0 percent of students were found to have bullying behavior, and when classified according to types of schools, more students from private schools than government schools were found to have bullying behavior. 34.9 percent of bullying behavior were throwing things at others, followed by kicking others (24.9 percent), punching others (23.4 percent), and slapping and hitting others (12.2 percent), respectively (Laeheem, Kuning, McNeil, \& Besag, 2008). Regarding Islamic private schools in Songkhla Province, bullying behavior among students was found to be at a moderate level (Laeheem \& Sungkharat, 2012).

Hence, the researcher was interested in investigating family and upbringing background of students in Islamic private schools who had bullying behavior in order to know about family and upbringing background of these students and how they were brought up. The results of this study would be useful for all parties concerned, and could be used in preventing and reducing bullying behavior among students in addition to providing help, improving and solving bullying problems so that students' behavior would not be more violent, and before the violence becomes a social problem that is difficult to solve.

\section{Methods}

\subsection{The Study Area/Target Group}

For this study, 15 Islamic private primary schools in Pattani Province were the study area because most bullying behavior began and was found at a great extent among primary school students with a tendency to increase in terms of violence (Laeheem, Kuning, McNeil, \& Besag, 2008). The target key informants of the study were: teachers, school personnel, students who bullied others, students who were bullied, and parents and guardians.

\subsection{Data Collection}

This qualitative study emphasized collection of data through in-depth interviews with 15 teachers and school personnel, 15 bullying students, 15 bullied students, and 15 parents and guardians.

\subsection{Data Analysis}

The data were analyzed by classifying them into categories and then comparing them using logic along with the context, concepts, theories and research. The grounded theory method was employed in data analysis with the following steps:

1) Open coding the data collected from the knowledge management stage, brainstorming, and criticizing stage. The data, as many as possible, were coded which could be sentence by sentence or paragraph by paragraph. The coding was divided into two levels. Coding of the data collected from verbal statements, arguments, supportive statements and exchanged statements. The data were broken or grouped according to their content and topics made by key informants. Then, coding of the data according to theoretical indicators where knowledge from related documents, concepts, and theories were connected to the content and topics obtained from key informants.

2) Categorizing the data. The data were grouped according to their similar codes or their shared attributes 
whether in context, conditions, or consequences. The data were analyzed based on the clear process of phenomena, data, content, and topics obtained from key informants.

3) Axial coding. The relationships between the categories and context were analyzed to obtain the categories and sub-categories as well as the core concept.

\section{Results}

\subsection{Case Studies of Students with Bullying Behavior}

\section{Case Study 1: Abdul}

Abdul was a 12-year-old boy studying in Mathayomsuksa 1 (Grade 7). His father was a teacher in an Islamic private school, and his mother was a housewife. Abdul was raised strictly, especially on the Islamic way of bringing up children. His parents tried their best to raise him up that way. For example, they were strict on making him pray five times a day and on praying voluntarily. They were strict on fasting during the Ramadan, learning the Al-quran, reading Dua (supplication) of every activity in his daily life and Islamic moral and ethics, and they never allow him to be involved in any kind of vices, etc. Because his mother was a housewife, she had enough time to be close to him as she brought him up and trained him according to the guidelines in the Al-quran and took Prophet Muhammad as the model, especially in explaining to him about good and bad behavior. For punishment by hitting, she did it only once in a while when he was very stubborn and disobedient. For every punishment, his parents explained about his bad behavior and that he deserved punishment. For example, once his father knew that he did not go to the mosque to pray for a few consecutive days but went to a game parlor near the mosque instead. When his parents asked him about his praying, Abdul insisted that he went to pray every time and his friend could be a witness. When his father explained to him about the bad effects of abandoning praying and bad effects of lying, Abdul confessed and apologized to his parents and agreed to take punishment by being beaten with a bamboo stick five times.

From talking to and asking Abdul about bullying others, he admitted that he bullied others regularly, mostly children of the same age and did it in any place that he had a chance to, and he chose to bullied them in many ways such as punching, slapping, hitting, kicking, pushing, and blocking the way, etc. The most violent bullying was when he and five other boys bullied a boy in the school restroom area in one late afternoon after school. The boy was hurt severely and could not go to school for many days. The incident was witnessed by some students who dared not intervene or help but stood there watching because Abdul threatened them not to tell anyone otherwise they would be bullied even much more than that boy. The boy who was bullied told about the bullying to his parents who filed a complaint with the school administrators. The school investigated and punished Abdul and his fellow bullies by suspending them from school.

Abdul was known as a big bully in the school because many students named his group "Rayatani Gang". Abdul was the gang leader that students were afraid of and worried whether Abdul would bully them and how. One student who was a small boy and was bullied by Abdul said that "Abdul often kicks my buttock, slaps my head, pushes me, and pinches me and challenges me saying "Do you want to box, son of a lizard?". Another student said that "Abdul often blocks the way, punches my chest, kick my legs, squeezes my throat, pushes me so that I collide with other students and he also pushes me hard to make me fall." Bang Hussein, a janitor also gave information about Abdul's behavior that "Abdul is a student that always asks for troubles and bullies others by kicking, slapping, hitting, punching, squeezing others' throats, and pushes other students."

\section{Case Study 2: Hasiyah}

Hasiyah was a 10-year-old girl whose parents had their own business and went out to see their customers everyday. Thus, they did not have much time to teach or train her, and had to ask her grandparents and other relatives to take care of her. Hasiyah's mother said that "My husband and I have to go out very early in the morning everyday to see our customers and deliver goods in Pattani, Yala, Narathiwat, and Songkhla. This is our false not having enough time for our daughter and not having much chance to talk to her about her study at school, about religious practice and about other behavior in general." From talking with Hasiyah's grandparents, we learned that she repressed her feelings and liked to be alone, gets violently angry, short-tempered, and she played with her friends and relative with violence such as playing police fighting with a criminal or a girl quarrelling with another girl about taking the same man as their boyfriend.

Hasiyah's bullying behavior was expressed through physically injuring others by pushing, pinching, slapping, hitting and throwing things to others, etc. In addition, she hurt others emotionally such as making fun of others' weak points, calling others by their parents' names, making fun of others' parents' occupation, making fun of others' physical appearance, etc. Hasiyah said that the most violent bullying she did was that "I followed the girl 
I hated most to the toilet behind the school building, and I splashed water on her until she was soaking wet and then some other girls helped me mobbing her by hitting her, pulling her hair and trampling her with our feet". Some students saw the incident but no one dared to help or stop it because they were afraid that Hasiyah might physically hurt them. Hasiyah also threatened the girl she bullied not to tell teachers, her parents, and other students about the bullying. Hasiyah told the girl that if anyone asked what happened to her, she had to say that she slipped on the floor and fell down in the restroom. Otherwise she would be physically hurt everyday.

From asking Hasiyah's parents and grandparents about her bullying behavior at school, nobody in the family knew that Hasiyah bullied other students at school because the school had never notified them. However, the family said that they thought that Hasiyah might have some bullying behavior but they did not know how severe it was. Hasiyah's homeroom teacher said that "I didn't know that the students had bullying behavior because no student had told me at all". In addition, Hasiyah herself gave us some information about her own upbringing that "May parents are not interested in me. They work very hard everyday. They leave me with my grandparents and that make me feel lonely and frustrated all the time".

\section{Case Study 3: Amina}

Amina was an 8-year-old girl who was raised by her grandmother because her father had to work as a construction worker, and her mother was a vendor in the fresh market. So her parents did not have time to bring her up until the time she had to start going to school. That was when her parents brought her back from her grandmother's. However, she was mostly with her mother because her father did not have time to be with her which was just the same as before. From asking Amina's mother about her bringing up, she said that her husband and she herself did not have time to raise Amina but they gave Amina things and money to show their love and care for her. As a result, Amina was aggressive and did not obey her. She noticed that what Amina wanted was not the things she gave her. When Amina had to go to school, she found out many times that Amina had bullying behavior and always bullied others.

Amina said that she wanted attention because she had no one to play with. She expressed herself using impolite words and she was aggressive such as scolding others, making fund of other's skin color, physical appearance and throwing things at them, etc. She bullied others during breaks and lunch hours. Other girls played together and had fun but she had no one to play with because she had bullying behavior. This made Amina very angry and scolded her friends who did not want to play with her. She was called a "black girl" or a "short girl" or a "fat girl". Sometimes she threw things at other children to hurt them. Amina talked about an incident when she bulled another girl and was punished by her homeroom teacher, and her parents were invited to the school. She said "Once I threw a stone at someone's head and there was some bleeding". Mrs. Amita, the teacher, said that bullying among students could happen easily in school and could not be eliminate in a short time; however, there should be constructive ways to reduce the violence of bullying such as teaching students to share. She also said that because students were brought up differently, schools and parents should share information in order to find ways to solve bullying problems among students correctly and effectively.

\section{Case Study 4: Anif}

Anif was a 12-year-old boy in his Prathomsuksa 6 or $6^{\text {th }}$ Grade who was big and strong. He bullied other students whenever he had a chance to. His father was a construction contractor and his mother was a trader. He grew up in a family with domestic quarrels and violence, verbally and physically. Therefore, Anif had seen violence continually and saw how a stronger person dominated. When he did something wrong, his parents punished him violently such as beating him with a clothes hanger, a broom, or a bamboo stick, etc., rather than asking him why he did it first, and his parents never explained to him the reason why he was punished. When his parents quarreled, they blamed it on him and used rude words with him. When asked how he felt deeply, Anif said he did not like violence but he had seen problems solved with violence and thought that it was the right method he should use to deal with or to solve the problem or when he did not like someone at school.

At school, Anif also faced many problems in addition to the problems he had at home. Anif said he was not afraid of anyone at school nor was he afraid of being punished. Thus, he often violated school rules and regulations such as escaping from school, not dressing properly, bullying students that he did not like or that were weaker. He did not care when he was punished for his wrong doings. He felt he was important as he was chosen leader of his gang and he could order anyone to do anything. During the lunch hour, Anif took his gang to stand along the corridor and put their legs out to make other people trip over and fall down as they stumbled over the gang's legs. When someone fell down he accused that person and punched him or squeezed his throat to make him cry. When Anif went to the sports field, he always snatched sports equipment from others even though he knew that the people he bullied would not like it. He said he avoided showing his bullying behavior when 
teachers were around, and he bullied others whenever he had a chance to. He injured boys physically and made fund of girls' skin color, their parent's occupations or took things from girls and hid them away.

From interviewing Anif about the type and characteristics of his bullying, he said that he enjoyed calling girls names like a "duck dark girl", a "charcoal dark girl", a "totally dark girl", a "darkest ever girl", a "fat dark girl", and a "short dark girl". Sometimes he took his gang to make fun of other students such as making fun of their parents' names, their physical appearance saying that they were short, dark, fat, jumbo, kinky, hanging, etc. For making fun of the students, he used such words as a cry-baby, a born-loser, an orphan, etc. In addition, he also tried to obstruct others from befriending with his victims or with people he did not like, and obstructed them from playing or doing activities in the group. He once took away the pants from a boy who was in the toilet to make him come out of the toilet half naked. Sometimes he threw water to make the person wet, and sometimes he locked the person in the toilet. Anif's friends said that he persuaded them to write on the walls of the restrooms using impolite words, rude words, hateful words and disgusting words to scold, slander, let out feeling and emotion, and to challenge. Some phrases were with the names of his victims that resulted in other people making fun of the victims.

Some other friends of Anif also gave information about him. One said that "I used to go with Anif to bully students in the school canteen by cutting in line to buy food, and took the table that other people were about to sit. He did not let anyone sit in some seats saying that the seats were already taken or reserved for someone else". Another boy said that "...Anif once took the rice on my plate and took someone else's drink. He also stuck gum on some chairs and took the food from a student who had just bought it. He also pushed people out of the queue, slapped them on the head, slapped them on their shoulders, and twisted their hands. Students who were bullied did not retaliate because they were afraid of him".

Anif was the ringleader of his class or even of the school. He enjoyed bullying other students everyday but nobody dared to tell the homeroom teacher, or teachers on the governing board, or even their parents because they were afraid that Anif might bully them or take revenge on them in a more violent form. Anif threatened all his victims saying "If I am punished, I will take revenge and hurt your even more severely". This made some students think that bullying others could be done and they will not be punished for doing it. Some students joined Anif's gang and they had to bring something to the gang leader everyday otherwise they would be bullied or even chased out of the gang. Therefore, if they did not want to be bullied, they had to give some snack or something to Anif everyday.

The homeroom teacher added that he had always known that Anif was roguish and bullied other students and threatened them to give him something because many students reported bullying incidents to him. He had warned Anif three times and after that no students told him about Anif's bullying again. He said that he did not believe that Anif could stop his misbehavior but no one dared to tell him about Anif again. This was because they were afraid that Anif would bully them again.

When Anif was asked whether he was bullied by anyone, he said when he first came to school, he was often bullied by older or stronger students and he did not like it at all and he cried. When he told a teacher about it, he was consoled but the bullies still continued bullying him and the bullying did not become less. He learned that people who bullied others would not get bullied. Therefore, he began to bully other students. He started with victims of the school and then expanded his bullying to students that he did not like. If anyone fought back, he would ask his gang to mob that person, and if anyone told the teacher, he would try to hurt that person as a way to threaten others. Anif also said that he was happy and felt that it was a lot of fun being at school and it was even more fun when he bullied someone. However, when he returned home, he was a victim and he did not like it at all and wanted to go away. When he was at school, he felt he had authority being the leader who could order other people but when at home, he was sad and depressed and had to witness his parents' quarrels and fights and sometime he was punished, and that made him think there was only violence and cruelty at home.

\section{Case Study 5: Latifah}

Latifah was a Mathayomsuksa 1 (Grade 7) student. Her parents were native fishers. Latifah were from a problematic family where parents did not pay much attention to religion and indulged their children. As a result, Latifah became roguish and liked bullying other students. She said that "I choose to bully someone smaller, weaker and physically impaired. I mostly bully them verbally making fun of their appearance, their shape, and their face by calling them short, fat, a toothpick, etc. I also make fun of their skin color such as black, pale, and charcoal, etc., and make fun of their physical impairment such as squint-eyed, crippled, and distorted mouth, etc. I also bully someone physically such as slapping them on the head, pushing, pulling the chair away so that the person falls down, and pinching, too. I also threaten and challenge them." 
Latifah used the lunch hour and breaks to bully others all around the school area, and sometimes she stood in the hallway to block the way of some students that she did not like, or sometimes she walked to collide with someone intentionally and took the opportunity to push the person on the chest, pinch, pull the head scarf down, slap, hit, squeeze the throat, push the person to fall down and accuse her by saying "Watch out the way you walk. Are you looking for trouble? Sure, you'll find it!" She always made her victims cry. Her victims were usually someone younger or in the same class rather than someone older; she chose someone who did not have many friends or was not in a group. She did not care if her victim was a boy or a girl. On the day that no students walked to where she stood waiting, she would persuade her gang to go and look for trouble bullying others. She interfered their playing and doing activities by saying things that would make them angry or embarrassed, or she would take away the sports equipment that they were using. If anyone showed their dislike, Latifah would threaten him/her or squeeze and twist his/her wrist to make him/her apologize, surrender, and protest no more. Some victims cried and ran away, and no one dare to tell the teacher about it because they were afraid that Latifah would take revenge. She threatened them saying that if she was punished by the teacher, she would hurt them many times more severely.

Latifah also said that in addition to her being spoiled by her parents, she experienced violence from quarrels and fights between her parents and her relatives so often that she was tired of such incidents. She felt that her parents and relatives always solved their problems using violence. Her mother said that she did not know that Latifah was roguish and always bullied others because the school never informed her about it; when Latifah was at home, she was a good girl and was loved by her parents and all her relatives who indulged her every whim. Furthermore, her homeroom teacher said that she did not know that Latifah was roguish and bullied others because nobody had told her and she saw Latifah as a jolly happy girl who was a lot of fun.

\section{Case Study 6: Abdullah, Alam, and Safi-ee (the Spiderman Gang)}

Abdullah was 13 years old and in Mathayomsuksa 1 (Grade 7). His parents were rubber tapper and fruit farmers. He was from a problematic family with violence. He was often punished violently. His parents did not pay much attention to religion and did not see importance of religious practice because they had very little understanding about the religious principles. They raised Abdullah without much interest in how he was, what behavior he had, how he expressed his thought and feeling, and how he lived. As a result, Abdullah became roguish and always bullied others. Abdullah talked about how he bullied other students saying "I usually bully someone who is smaller or weaker by kicking his buttock, slapping on his head, pushing, and pinching and asking "Do you want to box, son of a lizard?", and the person is usually too afraid to say yes and so I like to bully him more than others." Most of Abdullah's victims were usually physically impaired or smaller than him, and they never retaliated or report the incident to the teacher as they were afraid of Adullah's threat.

In his gang, there were two more boys who usually went around to bully others when teachers were not around. They were Alam and Safi-ee. The three boys had got together for some time to bully other students and to prevent others to bully them as well; they called themselves, "the Spiderman Gang".

Alam was also a 13-year-old boy studying in Matthayomsuksa 1 (Grade 7). His parents were killed in the unrest situation so he lived with his paternal grandparents who made their living on being hired for odd jobs. Alam said that his gang usually used the lunch hour and breaks to bully other students on the hall way by standing in others' way so that they collided and he would punch that person on the chest, kick his legs, squeeze his throat and push him down on the floor and ask "Why did you walk that way? Are you looking for trouble? You will find it for sure." The victims did not dare to say anything. Most of the victims were younger or the same age as Alam, and they did not want to fight back. Alam usually chose a student who had very few friends or who was not in a group. On the day that no one passed where he stood waiting for a victim, he got together with Abdullah and Safi-ee to bully students around the school physically and verbally. They also made fun of others, challenged them to box, took their sports equipment away, etc. If the victims did not like it, they fought and it always ended up with Alam as the actor or attacker.

Safi-ee was 12 years old and studied in the same class as the other two boys. Safi-ee was a strong-built boy whose parents were divorced and each had a new family. He lived with his mother who was a rubber tapper and fruit farmer. He said that he joined Abdullah and Alam because he was bullied but after joining the group nobody bullied him anymore. Personally, he said he did not like bullying because he knew how the one being bullied felt but to survive and for his own safety he had to join the other two boys to bully other students.

The three boys usually bullied girls as well and they did not care whether it was the girls' area or not like the restroom or bathroom for girls to clean themselves before praying. They peeped at girls taking their head scarves off and when the girls screamed the three boys were happy. They also often pulled girls' head scarves off that 
made the girl cry.

\subsection{Analysis of Family and Upbringing Background}

The data from the case studies illustrated that upbringing affected personality building of children when they grow up and spend their life in society. Child upbringing and family life can influence the child's behavior that is expressed when stimulated physically and psychologically. Students' bullying behavior is a result of parents' violent behavior towards family members, and of aggressive mothers who swear using impolite words and scold when they experience something undesirable. As Latip, a teacher on the governing body of a school revealed about upbringing of bullying students that "Students who like bullying others are usually those from families where parents use violence. They don't hold on to the religion and they take side with their children even though their children are wrong. Some bullying students are from family where parents are drug-addicts, gamblers, or involved in all vices."

Students grown up from families that use violence in solving problems will absorb the said behavior and take it as social actions acceptable by their peers. Some might think their actions are acceptable when they do something wrong, and no one in the group show disagreement or protest. Misunderstanding can come from mis-upbringing that leads children to have misbehavior that is undesirable for society when they grow up and choose to have personality for their existence. As Anif said "I grow up among quarrels and continuous violence in speaking and actions of my parents. Sometimes I get punished severely with, for example, a clothes hanger, a broom, and a bamboo stick. Many times, my parents' quarrels end with punishing me, especially with the use of rude words that result in my learning to solve problems with violence and I think that it is the right way to deal with problems or when I don't like anyone at school."

Moreover, a teacher named Sayid said that students with bullying behavior were usually from families with domestic problems such as using violence, being so strict that their children were uncomfortable or frustrated, or being to busy to have time to teach and train their children closely. As seen in the case of Abdul whose parents tried to be strict with him so that he grow up in the Islamic way. He was frustrated and released his frustration by bullying other students. In the case of Asiyah, her parents left her to her grandparents and relatives to raise her up. For Amina, she was brought up by her grandmother because her parents were too busy working and did not have enough time to teach and train her as they should have had.

Therefore, it can be said that family and upbringing background can directly affect students' behavior. Good upbringing or good parental models influence students' personality when they have to interact with others in society. However, students who are from families with problems, such as families with divorced parent, drug-addict, gamblers, and those involved in all vices, can absorb these bad environments in their feeling and thought that may probably lead them to their being unable to cope with stimulants that affect them physically and psychologically, especially in dealing with them appropriately. It is noticeable that some of the parents did not know that their children had bullying behavior as a teacher named Phakdi talked about the case that a student regularly committed serious wrongdoings and was finally expelled from school. It is a case to ponder. When the school reports that the child is roguish and regularly violates schools rules and regulations, parents usually do not believe it and defend that their child is a good child when at home and never shows any sign of misbehavior. Sometimes, parents do not perceive all aspects of their children's behavior; thus, they should regularly consult with the teacher and monitor their children through the teachers that are close to their children when at school. Children who grow up in families with problems and use violence or use rude words when they have domestic problems will absorb and use them when they face problems and it can become their habit until they are adult if they have not been through the process of socialization or are not trained to solve problems with better ways than using violence.

Growing in society with diversified social factors can form different personalities for children depending on social value, and the socialization process they have had. In family with problems about violence, children can absorb various forms of violence in themselves; however, whether they would use them with other people or not depends on many factors that stimulate them. It is important for children to go through a socialization process and training from their families as these can mitigate the growth of the disease called violence in the children. In the case of Abdul who said that "My parents are so strict on raising me the Islamic way that I feel uncomfortable and frustrated and I have to find a way to let out my frustration by bullying my fellow students." Hence, it can probably be said that family and upbringing background have effects on students' bullying behavior. Many students who were interviewed could think of many ways to bully others, to bully back or to use violence to retaliate when they were bullied. Students who bullied others had violent behavior that they probably absorbed from different media and might express such behavior at any time and could become violent persons who enjoy 
bullying others. This can be pondered that children who lost their parents in the unrest situation are growing silently a violent area and as they are students, bullying their fellow students is like training them to use violence. The victims of their training are students being bullied who are also ready to turn themselves to be the doers at any time in order to be free from being underdogs.

As mentioned above, the important role of family and upbringing background can influence children's personality, especially their behavior when they go out from home to school which is a social setting where children of diversified social backgrounds get together. Children who grow up with indulgent parents who take side even when their children are wrong, when they go to school and have many types of friends, they may have problems as a result of their indulgence or because of their thinking that other people should accept their actions no matter if they are wrong or inappropriate. This is because they are accustomed to being accepted by their parents. Sometimes this can lead to their bullying behavior or their challenging the rules and regulations observed by other students. When the school invites their parents to the school to acknowledge their children's wrongdoing, the parents blame it on the school and they want the school to be responsible if their children are bullied or hurt. Beedean, a boy who had a problem with another boy from an indulgent and over-protective family said that the boy was roguish and liked to show off to get attention and to be talked about, and also said that he would break the school rules and regulations but he was always protected by a teacher in the school governing body because his parents knew the school administrators. However, when students in Beedean's group had a problem with that boy, his parents made a big deal out of it and did not care whether their son was right or not.

In this case, Mr. Yusuf, deputy manager of the school said that the student was over-spoiled by his parents, and that caused his roguish behavior, and he gradually bullied more and more students. When the school informed his parents about the boy's behavior, the parents said that their son was not wrong but the other students were wrong. The school was concerned with the behavior and worried that similar problems could happen with other students in the future. The rules and regulations of the school about punishment were not clear and depended on decisions made by teachers in the governing body. As a result, there had been cases that students who committed the same type of wrongdoing had different punishment while some students were not punished at all for committing wrongdoings or had privilege over other students because their parents knew school administrators. Unclear and inconsistent school rules could probably be a cause of students' bullying behavior if students had risk habit that could cause undesirable behavior. Thus, indulgent upbringing can bring about students' bullying behavior when they are in the schooling system. This is due to students' being accustomed to having power and showing their power through immediate response to their desires from their family.

\section{Discussion and Conclusions}

The analysis results above indicate that students who bully others are from families with problems about family and upbringing background. That is, family and upbringing background are very important to students' behavior. For example, children who are from families with divorced or separated parents can feel lonely and that can directly affect them psychologically. Children from family with aggressive emotion and express it through hot temper, serious anger, aggressiveness, abusiveness, may acquire similar behavior. These problems affect children's behavior (Arayawinyu, 1999). While children are neglected by their parents, they do need loving care from their parents; however, they do not receive it. Consequently, they have problematic behavior and become unfit for society and try to get attention using various methods such as being restless, interfering others, being noisy, being roguish, etc. On the other hand, children who are extremely pampered by their parents can also have behavioral problems such as being selfish, bullying others, being irresponsible, and looking down on others (Intarachote, 1993). Supportive upbringing, and reasoning upbringing have inverse relations with aggressive behavior while the relation of controlling upbringing and aggressive behavior is a direct variation (Teosound, 2004). This corresponds with the findings of this study that most children who break the law and have violently aggressive behavior are from broken homes where parents do not care for their children but abuse them and beat them; and the parents themselves quarrel, fight and beat each other (Sukchan, 1999). Upbringing is related to children's and youth's wrongdoings (Srikosol, 2002). Parents who are not understanding of children's feeling, needs, loneliness, and lack of spiritual refuge can result in children's undesirable behavior (Prommana, 2000). Witnessing their parents fight and beat each other and being attacked by family members, children can learn to have violent behavior (Hickey, 1991; Bowers et al, 1992; Olweus, 1995; Webster-Doyle, 2000).

Family and upbringing background are factors leading to students' bullying behavior that is related to imitative behavior resulting from environmental violence that is an important factor influencing children's behavior (Arayawinyu, 1999). Furthermore, when children see or receive information about violence from people close to them, they can absorb and imitate the violent behavior that can increase risk for them to use violence and commit 
wrongdoings (Ahmed \& Braithwaite, 2004). This also contributes to more violent behavior as children learn violence from what they experience from their families (Hickey, 1991; Webster-Doyle, 2000). Children learn behavior from people around them and imitate the behavior they have learned as most children think that aggressive behavior and violence are normal behavior and can be used in their life (Coloroso, 2003).

Violence displayed by parents results in students' negative behavior as they learn such behavior from observing the model and absorbing the behavior that increases their violent behavior without them knowing it. As children see the use of violence as normal, they eventually use it with people around them in their daily life and use it in solving problems. It is said that children begin to imitate people closest to them who they respect and they also imitate other people around them; thus, they learn from what they see. Most children think that displaying aggressive behavior and violence is normal and can be practiced in their life (Bandura, 1975; Coloroso, 2003). Aggressive behavior and conflicts between parents can set a model for children and affect children's emotionally and psychologically. This can develop to emotional problems, violent behavior, and bullying behavior that they use in their daily life (Baldry, 2003; Espelage \& Swearer, 2003).

As can be seen, the influence of violence is bad experience for children, a starting point of their violent behavior, and a stimulant for their bullying behavior. The model or experience that children have can mislead them to accept violent behavior as normal in everyday life. Moreover, violence that children see can stimulate them to imitate, especially when they see it repeatedly and try to find justification for it, or accept it as an alternative for problem solving. According to Brendtro and Long (1995), children from families with frequent domestic quarrels and conflicts that are unhealthy environments can make them stressed for a long time, and as a result, they would protest against the adults and think that if they want to be accepted by others, they have to use force and violence. Violence in games also enters their mind making them think of violence as guideline for practice as they see that violence can be used to immediately solve problems in the games they play. Remschmidt (1993) stated that family is one factor that can increase violence, especially families that use violence to stimulate violent behavior. In addition to this, aggressiveness and violence in the media result in children's desire to display aggressive behavior or to accept that aggressive behavior as normal for daily life, and accept violence as an alternative for problem-solving. Laeheem and Baka $(2009 ; 2011)$ found in their study that parents' quarreling, fighting and beating each other can lead to violent behavior and aggressive behavior of youth in the three southern border provinces of Thailand. Laeheem, Kuning, and McNeil (2009), and Laeheem, Kuning, McNeil, and Besag (2008) in their study found that seeing parents quarrel, fight and beat each other, and playing games can result in students' bullying behavior in Pattani province.

The results of this study is beneficial to people and organizations directly related to children such as teachers, parents, guardians, religious leaders, local leaders, social workers and government officials in various organizations that have to give importance, pay attention and provide care in helping and improving children's behavior as well as to prevent children from having more violent behavior. For example, a screening form to measure risk behavior in bullying should be used which is one way to know about students' bullying behavior, and as a tool in consideration for classifying children who are in the risk group or the group with bullying behavior according to the screening criteria. This is to help prevent or solve the problem, to provide help that is correct or corresponds with the persons quickly and with a clear goal that sometimes and in some cases have to be solve urgently, for example, a screening form for risk behavior in bullying others among students of private Islamic schools in Songkhla Province (Laeheem \& Sungkharat, 2012). A bullying prevention program should be used, especially a program that is suitable and efficient and has been tested or piloted academically such as a self-control program (Lhamlert, 2009), a yoga practice program (Sonchan, 1999), learning to play a Thai musical instrument and self-control (Comwatjanung, 2001), learning techniques from the consequences that the model receive (Kriangsri, 2004), and group consultation (Tragulsuppachai, 2004), etc.

Parents and guardians, in particular, must realize and attach importance to their children's feeling; they have to be patient, to forgive, and to trust each other in order to be a happy family. Moreover, relatives as well as related organizations have to cooperate and promote happy family life, and take a stand against domestic violence. This is because the findings of this study revealed that family and upbringing background affect children's personality when they go to school. Children who face violence in their families have a tendency to solve problem using violence, but children who are from indulgent families usually use power over others when in school. Furthermore, it was found that punishment when students commit wrongdoings can enable most students to have desirable behavior. For further studies, it is recommended that research to find ways to solve bullying behavior should be conducted. Studies should also be performed on development of a screening program for risk behavior in bullying, and of bullying reduction and prevention programs in order to prevent bullying behavior that is increasingly with more violent and can be a social problem that is difficult to solve in the future. In addition, 
studies should be conducted on behavior of students who lost family members in the violent situation that affect the students' personality when they enter social life in school, work or community.

\section{Acknowledgements}

We are grateful to the Thailand Research Fun (TRF) for support this project.

\section{References}

Ahmed, E., \& Braithwaite, V. (2004). What, me ashamed? Shame management and school bullying. Journal of Research in Crime and Delinquency, 41(3), 269-294. http://dx.doi.org/10.1177/0022427804266547

Arayawinyu, P. (1999). The behavioral problems of children. Bangkok: Wankeaw.

Astor, R., Meyer, H., Benbenishty, R., Marachi, R., \& Rosemond, M. (2005). School safety interventions: Best practices and programs. Children and Schools, 27(1), 17-32. http://dx.doi.org/10.1093/cs/27.1.17

Baldry, A. C. (2003). Bullying in schools and exposure to domestic violence. Child Abuse \& Neglect, 27(7), 713-732. http://dx.doi.org/10.1016/S0145-2134(03)00114-5

Bandura, A. (1975). Social learning and personality development. NJ: Rinehart \& Winston.

Baron, R., \& Neuman, J. (1996). Workplace violence and workplace aggression: Evidence on their relative frequency and potential causes. Aggressive behavior, 22(3), 161-173. http://dx.doi.org/10.1002/(SICI)1098-2337(1996)22:3<161::AID-AB1>3.0.CO;2-Q

Bowers, L., Smith, P., \& Binney, V. (1992). Cohesion and power in the families of children involved in bully/victim problems at school. Journal of Family Therapy, 14(4), 371-387. http://dx.doi.org/10.1046/j..1992.00467.x

Brendtro, L., \& Long, N. (1995). Breaking the cycle of conflict. Educational Leadership, 52(2), 52-56.

Chanhom, P. (1998). The associations between family upbringing and aggressive behavior (Unpublished master's thesis). Mahasarakarm University, Mahasarakarm.

Coloroso, B. (2003). The bully, the bullied, and the bystander: From pre-school to high school: How parents and teachers can help break the cycle of violence. New York: Harper Collins.

Comwatjanung, W. (2001). The effect of Thai music practicum and self-control on aggressive behavior of mattayomsuksa two students in Prachinkallayanee school Prachineburi province (Unpublished master's thesis). Burapha University, Chonburi.

Dauvergne, M., \& Johnson, H. (2001). Children witnessing family violence. Canada: Juristat, Statistic Canada.

Edleson, J. L. (1999). Children's witnessing of adult domestic violence. Journal of Interpersonal Violence, 14(8), 839-870. http://dx.doi.org/10.1177/088626099014008004

Espelage, D., \& Swearer, S. (2003). Research on school bullying and victimization: What have we learned and where do we go from here? School Psychology Review, 32(3), 365-373.

Farrington, D. (1993). Understanding and preventing bullying. In M. Tonry, \& N. Morris (Eds.), Crime and Justice. Chicago: University of Chicago Press.

Herrera, V. M., \& McCloskey, L. A. (2001). Gender differences in the risk for delinquency among youth exposed to family violence. Child Abuse \& Neglect, 25, 1037-1051. http://dx.doi.org/10.1016/S0145-2134(01)00255-1

Hickey, E. (1991). Serial murderers and their victims, brooks. CA: Cole, Pacific Grove.

Intarachote, P. (1993) The effect of reality therapy on bully behavior of prathomsuksa five students of chumchombanputei school in amphoe Wichian Buri, Changwat Phetchabun (Unpublished master's thesis). Srinakharinwirot University, Bangkok.

Jaffe, P. G., Wolfe, D. A., \& Wilson, S. K. (1990). Children of battered women. CA Sage: Newbury Park.

Kriangsri, N. (2004). The vicarious learning to model on reducing aggressive behavior or prathomsuksa five students of Pattaya city schools (Unpublished master's thesis). Burapha University, Chonburi.

Laeheem, K., \& Baka, D. (2009). Risk factors related to youths' violence behaviors in the three southern border provinces of Thailand. Songklanakarin Journal of Social Sciences and Humanities, 15(6), 897-911.

Laeheem, K., \& Baka, D. (2010). A study of the Thai Muslim youth's way of life to maintaining peace in the three southern border provinces of Thailand. Songklanakarin Journal of Social Sciences \& Humanities, 16(6), 973-988. 
Laeheem, K., \& Baka, D. (2011). The risk factors are related to Thai Muslim youth's aggressive behavior in the three southern border provinces of Thailand. NIDA Development Journal, 51(3), 59-90.

Laeheem, K., \& Sungkharat, U. (2012a). Development of screening inventory for students at risk of exposure to bullying behavior in Islamic private schools, Songkhla province. Kasetsart Journal: Social Sciences, 33(2), 175-187.

Laeheem, K., \& Sungkharat, U. (2012b). Relationships between affective characteristics factors, family upbringing factors, violence influence factors, and bullying behavior of Islamic private schools students' in Songkhla province. Journal of Liberal Arts, Prince of Songkla University, 4(2), 65-82.

Laeheem, K., Kuning, M., \& McNeil, N. (2009). Bullying: Risk factors becoming 'Bullies'. Asian Social Science, 5(5), 50-57.

Laeheem, K., Kuning, M., McNeil, N., \& Besag, V. E. (2008). Bullying in Pattani primary schools in southern Thailand. Child: Care Health and Development, 35(2), 178-183. http://dx.doi.org/10.1111/j.1365-2214.2008.00890.x

Lhamlert, S. (2009). A study of aggressive behavior and self-controlled program development to reduce aggressivebBehavior of female juveniles (Unpublished master's thesis). Srinakharinwirot University, Bangkok.

Marano, H. E. (1995). Big bad bully. Psychology Today, 28(5), 50-82.

National Research Council. (1993). Understanding child abuse and neglect. Washington DC, USA: National Academy Press.

Olweus, D. (1995). Bullying or peer abuse at school: Facts and intervention. Current Directions in Psychological Science, 4(6), 196-200. http://dx.doi.org/10.1111/1467-8721.ep10772640

Pepler, D., \& Sedighdeilami, F. (1998). Aggressive girls in Canada. Ottawa: Applied Research Branch, Strategic Policy, Human Resources Development Canada.

Prommana, R. (2000). Factors causing undesirable behaviors in the opinion of mathayomsuksa three students in educational opportunity expansion schools under the office of Wang Nua district primary education, Lumpang province (Unpublished master's thesis). Chiang Mai University, Chiang Mai.

Remschmidt, H. (1993). Cycle of violence. Deutsches Aerzteblatt, 39(Winter), 35-40.

Rossman, B. R., Hughes, H. M., \& Rosenburg, M. S. (2000). Children and interparental violence: The impact of exposure. Philadelphia PA: Brunner/Mazel.

Sonchan, S. (1999). The effect of hatha yoga on aggressiveness of mathayomsuksa two students (Unpublished master's thesis). Burapha University, Chonburi.

Southern Border Provinces Police Operations Center. (2006). Statistics of the unrest in the three southern border provinces of Thailand. Yala: Royal Thai Police.

Srikosol, S. (2002). Juvenile delinquency: A case study of serious cases (Unpublished master's thesis). Kasetsart University, Bangkok.

Sukchan, C. (1999). A study of the cause of juvenile delinquency in Bangkok (Unpublished master's thesis). Kasetsart University, Bangkok.

Taosound, N. (2004). The relationship between child rearing practices and aggression of secondary student, Chiang Mai Province (Unpublished master's thesis). Chiang Mai University, Chiang Mai.

Tapanya, S. (2006). The survey of students' bullying problem. Chiang Mai: Chiang Mai University.

Tragulsuppachai, T. (2004). The effects of rational emotive behavior group therapy on decreasing the aggressive behavior in classroom (Unpublished master's thesis). Burapha University, Chonburi.

Webster-Doyle, T. (2000). Why is everybody always picking on me? A guide to handle bullies. Middlebury, VT: Atrium Society Publications.

\section{Copyrights}

Copyright for this article is retained by the author(s), with first publication rights granted to the journal.

This is an open-access article distributed under the terms and conditions of the Creative Commons Attribution license (http://creativecommons.org/licenses/by/3.0/). 